\title{
Bank Risks, Regulatory Interventions and Deconstructing the Focus on Credit Risk
}

\author{
Anthony Okafor, $\mathrm{PhD}^{1^{*}}$ Javier Fadul, $\mathrm{PhD}^{2}$ \\ 1.College of Management and Technology, Walden University \\ 2.Contributing faculty College of Management and Technology, Walden University
}

\begin{abstract}
The risks that banks face have been exacerbated by the globalization and liberalization of the financial markets. The liberalization of the financial markets has exposed banks to a plethora of risks such as credit risk, liquidity risk, operational risk, counterparty risk, regulatory risk, systematic and reputational risks. A recurring discourse in the risk management literature is the perceived concentration of regulatory authorities on credit risk. This topic is reconsidered in this paper to critically evaluate the different risk types and to interrogate the assertion that regulatory authorities have focused more on credit risks of banks while shying away from other possible risks that banks face. Reviewing contemporary literature and regulatory interventions, we conclude that contrary to the claims that regulatory interventions have focused on credit risk of banks, attempts have been made to address in broad terms the gamut of risks that banks face.
\end{abstract}

Keywords: Bank risks, Regulatory interventions, Credit risk

DOI: $10.7176 /$ RJFA/10-8-09

Publication date: April $30^{\text {th }} 2019$

\section{Introduction}

The globalization of the financial markets has led to one of the most significant changes in modern banking since the great depression, and this has brought about changes in banking services and the amount of risks banks face (Raluca, 2012). The globalization of the financial markets refers to the utilization of communication technology to increase the efficiency of the financial markets and to lower barriers to international trade (Radu, 2012). The banking system has become a significant enabler in promoting trade and decoupling benefits of globalization across the world and the increased mobility of companies seeking business opportunities across the globe (Niepmann \& Schmidt, 2013). Banks remain a significant mechanism for the smooth transmission of both domestic and international trade and for channeling financial resources between borrowers and depositors and dealing with any risks that might arise (Bollard, Hunt \& Hodgetts, 2011).

The banking system act as the pivot on which other elements that enhance the growth of an economy revolves (Diallo, 2015). Because of the significant roles that banks play in supporting economic growth, the attention of stakeholders has been drawn to the need to continuously assess the risks that could impact the smooth operations of banks especially in discharging their roles to the economy. The risks that banks face have been exacerbated by the globalization and liberalization of the financial markets (Schmukler, 2004). Globalization has led to unprecedented growth in the financial markets and modern banking which has reduced the usually visible distinction between global and domestic markets. The increasing cross-border economic exchanges and the liberalization of the financial markets have increased the speed, size, and scope of capital flow across the world with significant risk implications for the banking system saddled with the onerous task of facilitating international transactions. The nature of banking services has changed from everyday banking such as opening savings and current accounts to becoming involved in complex investments and transactions.

National banks with domestic focus are not immune from the plethora of risks facing their counterparts with a global focus, the nature and impact of such risks might, however, vary depending on the level of exposure. While the liberalization of the financial markets comes with its immense benefits to the global economy, the downside is seen in the attendant risks that it poses to the banking system (Mitrovic \& Ljubic, 2015). The events of the 2008 global financial crisis have necessitated the raft of regulations that we have seen in the recent past. Efforts at harmonizing accounting standards have also intensified. Most of the regulatory interventions seem to have focused on managing the credit risk of banks and ensuring they remain liquid (Goodhart, 2005). However, given the dynamism of the financial markets, the risks that banks now face are multifaceted and needs to be fully explicated.

Consequently, the remaining part of this paper will be dedicated to discussing the nature and significance of the risks that banks face. Attempts will also be made to critically evaluate regulatory interventions, especially the assertion that regulatory authorities have focused more on credit risks of banks while shying away from other possible risks that banks face. Advice on how regulators can expand regulations to capture other forms of risks that banks face is also presented.

\section{Nature and Significance of Bank Risks}

The traditional business of banks is matching savers and borrowers in a manner that meets the risk appetite of the 
bank (Vyas, 2012, p.2). The business of banking in contemporary times has gone beyond matching savers and borrowers to engage in more complex transactions which expose banks to more risks. Competition has been described as a significant driver of risks in the banking industry because banks are ranked by size, profitability, and sometimes their client base (Danielsson \& Zigrand, 2015). Therefore, inordinate quest to maximize profit makes banks to take a considerable amount of risk thereby exposing them to uncertainties that could be destabilizing (Macey \& Miller, 1988). The nature of risks that banks encounter while carrying out their businesses vary depending on how complicated the transactions are and the creditworthiness of the banks' customers. Similarly, the impact that a risk could have also vary depending on the nature of the risk and level of exposure. Risk is described as any threat to the steady flow of a bank's income (Audu, 2014). The concern of management is usually how to approach risks they face with risk avoidance, acceptance, reduction, and transference as major strategies (Enriques \& Zetzsche, 2013). Broadly, the nature of risks that banks face can be categorized as presented below.

\subsection{Credit Risk}

Credit risk, also known as default risk, is the potential that a bank's customer or counterparty fails to meet its obligation to the bank in line with the terms of an agreement (Audu, 2014). Spuchl'áková, Valašková, and Adamko (2015) described credit risk as the unwillingness or perhaps the inability of a counterparty to make good its commitments to lending, trading, and settlement of financial transactions. Traditionally, credit risk is seen as the likelihood that a bank's debtor is unable to repay the amount owed to the bank including principal and interest (Audu, 2014). In some instances, debt collectors are commissioned to recover the amount owed thereby increasing the overall operating cost of the bank. Credit risk has severe consequences on the smooth operation of the bank, its cash flow and the overall stability of the business (Audu, 2014).

Poor credit risk management has been the bane of the banking sector and probably why it has received much attention. In a study on the relationship between poor credit management and bank failures in Nigeria, Ugoani (2015) found that poor credit risk management was the most prominent reason why banks fail in Nigeria citing Oceanic Bank, Bank PHB, Spring Bank, and Intercontinental Banks as examples. Also, while examining the impact of liquidity and credit risks on bank stability in the Middle East and North Africa, Ghenimi, Chaibi, and Omri (2017) revealed that banking failures were driven majorly by credit risk. The inability of banks to recover loans advanced to their customers could have significant implications on the bank's going concern. Because of the serious implication of credit risk especially on the going concern of the business, banks now have a unit mostly called Credit Risk Management (CRM) to help banks assess their credit risks.

\subsection{Liquidity Risk}

Liquidity risk is the risk that a bank might not be able to meet its short-term financial demands or contractual obligations (Scannella, 2016). Liquidity risk can also be viewed from a bank's inability to dispose of its holding in securities or other assets without suffering unacceptable losses either of capital or income during the conversion process. Generally, liquidity risk can be categorized into funding and market liquidity risks and can be determined by examining the liquidity ratio also called the quick ratio to ascertain the financial soundness of the bank (Decker, 2000). Quick ratio can be calculated as follows:

$$
\text { Quick Ratio }=\frac{\text { Current Assets }- \text { Inventory }}{\text { Current Liabilities }}
$$

The current assets are made up oг tne pank s ıquid assets or marketapıe securıtes, tne account receivable and other cash equivalents (Weston \& Brigham, 1997). A higher quick ratio reflects the bank's level of liquidity. Liquidity risk can become a significant challenge for banks who have considerable investments in securities issued by governments or corporate organizations. Liquidity risk was at the heart of the 2008 financial crisis (Antoniades, 2014). During the 2008 financial crisis, the challenge was the inability of financial institutions to dispose of their holdings in the U.S subprime mortgage debt because of the severe deterioration in the value of the security.

The collapse of the Northern Rock in the U.K was mostly due to liquidity issues (Shin, 2009). The bank's assets were more than its liabilities but had difficulties converting those assets to meet its financial obligation (Shin, 2009). Therefore, while a bank might have enough assets to cover its liabilities, becoming exposed to liquidity risk would have implications on the operating cost and profitability of the bank (Shen, Chen \& Kao, 2009). A bank could experience a run as seen in the case of Northern Rock if the bank is unable to access sufficient funds either through incurring more liabilities or disposing of its assets without suffering huge losses.

\subsection{Counterparty Risk}

Counterparty risk is another risk that banks face while carrying out their activities. The likelihood that counterparty to a financial contract will default or fail to live up to its contractual obligation is referred to as counterparty risk 
or default risk (Fath \& Stanley, 2011). Counterparty risk is also related to settlement risk which occurs when a counterparty defaults on its obligation when the other party has either delivered cash or security (Fath \& Stanley, 2011). Counterparty risk is usually a feature of over-the-counter transactions, which are contractual obligations, negotiated privately between two parties. When this type of risk occurs, the focus is usually on the potential loss of covering an open position. If cash has been delivered and the counterparty fails to deliver the security, this could create a settlement risk in the market as every derivative trade needs to be settled.

Counterparty risk was prevalent during the 2008 financial crisis, and this was evident when Lehman Brothers defaulted on its contractual obligations (Bullard, Neely, \& Wheelock, 2009). This created a systemic issue across the financial markets leading to several other financial institutions defaulting on the terms of their contractual obligations. The impact that counterparty risk would have on an organization depends on the level of exposure especially if the security that needs to be settled is out of the money. Counterparty risk could be very severe if it occurs and that is why banks now set up counterparty limits and periodically review such limits to ensure they minimize their exposures to institutions they consider weak.

\subsection{Regulatory Risk}

The financial industry is a highly regulated sector because of their importance to the economy (Rubin, 2014). Regulatory risk can be seen as any change in regulation that could significantly impact the activities of the business (Gentzoglanis, 2014). Another way banks are exposed to regulatory risk is that its operating license could be withdrawn or the operating conditions varied by the authorities thereby negatively impacting the value of the business (Price Water House Coopers, 2012.p.12). Regulatory risk could also lead to unpredictable hike in the cost of capital or minimum capital base as seen during the banking consolidation in Nigeria (Wright \& Mason, 2003).

The impact of regulatory risk on a bank could be severe. For instance, a regulatory pronouncement seeking to raise minimum capital base as seen during the banking consolidation in Nigeria led to the collapse of many banks as they could not raise the stipulated capital. Additionally, not fully comprehending regulatory expectations has led to hefty fines and reputational damage in some instances (Armour, Mayer \& Polo, 2017). A recent example can be seen in the fines imposed on four Nigerian banks for aiding unlawful repatriation of $\$ 8.1$ bn by the telecom giant, MTN (Central Bank of Nigeria, 2018). Therefore, to operate successfully in a highly regulated environment, banks need to take into account the regulatory risk they face.

\subsection{Systematic and Unsystematic Risks}

Banks are also exposed to systematic risk and unsystematic risks. Danielsson and Zigrand (2015) described systematic risk as the risk that involves the failure of the whole financial system. Systematic risk is a risk that is inherent in the entire market not necessarily a company's stock or one sector of the economy making this type of risk not diversifiable (Danielsson, \& Zigrand, 2015). An example of systematic risk was seen in Nigeria between 2014 and 2016 when the country had a foreign exchange crisis. The entire segment of the Nigerian market was affected; banks had their credit lines frozen, stock prices plummeted, some companies folded up, and jobs were lost. Countries like Argentina, Turkey, and Venezuela are currently experiencing this type of risk. Thus, systematic risk could have severe consequences on banks' ability to remain profitable or could even threaten their going concern when they occur, and regrettably, this type of risk cannot be eliminated through diversification (Audu, 2014).

Conversely, unsystematic can be diversified because unsystematic risk only affects a segment or a company's stock (Danielsson, \& Zigrand, 2015). While systematic risk is influenced by external factors and beyond the control of the entity, unsystematic risk can be controlled by the entity because it is internal to the entity (Audu, 2014). Banks holding securities of companies operating in a segment of the market may eliminate any potential risk arising from that sector by diversifying its portfolio through the inclusion of securities from other segments of the market. Therefore, the impact of unsystematic risk of banks is not as severe as that of systematic risk and could be minimized through a sound risks management strategy.

\subsection{Operational Risk}

Operational risk is one of the highly discussed risks in the financial sector. Operational risk is the risk associated with a breakdown or failure of the internal process, the people and systems (Basel Committee, 2006, p.144). Unlike systematic risk or market risk, operational risk is not inherent in the market or the system. They result from the inadequacies in the processes and systems put in place by the organization. Operational risk could arise from the failure of computer systems or batching error (Audu, 2014). Internet fraud or fraud associated with automated teller machines are examples of operational risk.

Operational risk could also be said to be partly responsible for the 2008 financial crisis. Dilley (2008) reported that systems put in place were unable to detect the financial standing of applicants seeking to obtain mortgage loans. Most of the applicants had poor credit records while some overstated their income and were able to secure a loan which they eventually were unable to repay (Dilley, 2008). As a consequence, many of these institutions 
folded up or were nationalized after the financial crises. Clearly, operational risk is a major risk confronting banks and this could be combated by implementing strong corporate governance and a robust IT infrastructure.

\subsection{Reputational Risk}

Reputational risk is another risk that banks face. Reputational risk depicts a deficiency in trust by stakeholders such as investors, shareholders, customers or regulators of a bank which is capable of impacting the image, credibility and business relationships of the bank (Bonime-Blanc \& Ponzi, 2017, p.8). The business of banking is one that depends on trust and a positive perception of its stakeholders to flourish. Reputation is an invaluable asset that provides a bank with a competitive advantage over its peers and can positively affect the financial performance of the company (Larkin, 2003).

Counterparties want to be sure of the credibility of the bank to keep to the terms of an agreement. Absence of trust makes it difficult for the bank to transact or be able to access funding. Also, customers want to be sure of the safety of their funds, and they could have access to it at any time. If reputation risk is not properly managed, the bank's revenue and by extension, the shareholders' value can be significantly impacted. Therefore, it is in the interest of the bank to ensure it maintains an excellent image to continue to enjoy patronage and sustain its business relationships.

\section{Regulatory Interventions to Risk Management}

Theoretically, the role of central banks or financial regulators is to guide financial institutions on risk-taking and to set appropriate limits to ensure the safety of depositors' and investors funds (Lahidji, 2008). Regulations by design are rules backed by governmental powers put in place by regulatory bodies to govern the activities of banks as it relates to risk management with specific focus on protecting depositor's funds (Ping, 2014).

The focus of regulatory authorities has been to improve the quality of regulations through a rigorous application of cost-benefit principles (Malyshev, 2008). This implies that regulatory interventions are directed at areas of highest impact which probably gives credence to the view that regulatory bodies have focused on the management of some risk types to the exclusion of other risks faced by banks. The major risks faced by banks include credit risk, liquidity risk, counterparty risk, operational risk, reputation risk, regulatory risk, systematic and unsystematic risks (Weber, 2013). There have been concerns that regulatory interventions on risk management in the banking sector have focused mostly on evolving policies and frameworks for containing credit risk (Goodhart, 2005). Opinions are divided on why regulators are more concerned about credit risk as opposed to the totality of the risks that threaten the corporate existence of banks.

Proponents of this view cite the primary focus of the Basel Committee at inception as part of the reason. The Basel Committee was established in 1974 by a group of 10 central banks following the banking and international currency failures and the Latin American debt crisis (Basel Committee, 2018). In 1988, the group reached an international agreement known as the Basel I Capital Accord to provide a common standard for internationally active banks (Balthazar, 2006. p.32). The framework was solely directed at credit risks that banks face followed by setting limits for capital adequacy ratios (Danielsson \& Zigrand, 2015).

Pointedly, the Basel committee stated that Basel I only assessed credit risk in relation to capital adequacy to the exclusion of other risks (Basel Committee, 1988, p.2). Mostly, the framework focused on the risk to banks assets, that is, the likelihood that counterparty might default but failed to account for other threats that banks are exposed to. This led to the criticism that regulators and rating agencies focused on the capital ratios of the banks but are not sensitive to the overall risks that banks face (Danielsson \& Zigrand, 2015). When Basel II was introduced in 2004, the focus remained credit risk but this time with the inclusion of operational risk (Basel Committee, 2005). Basel IV that was released in 2016 also focuses on containing counterparty credit risk even though it seeks to improve the weaknesses of the previous Basel Accord agreements (Cañamero, 2016).

Besides the Basel Committee, the response of accounting bodies such as the International Financial Reporting Standards (IFRS) and the Financial Accounting Standard Board (FASB) give credence to the claim that much attention has been geared at containing credit risk over other types of risks. IFRS 9, which assesses Expected Credit Losses (ECL), was introduced by the IFRS to help banks measure the weighted average credit losses on a portfolio (KPMG, 2017). Also, the Current Expected Credit Loss (CECL) was introduced in 2016 by the FASB to measure losses expected over the life of loans advanced by banks (Cañamero, 2016). Regulatory authorities such as the European Banking Authority (EBA) also recently issued a risk management framework that focuses primarily on credit risk management. EBA (2018) broadened the internal rating based approach and provided clarity on acceptable credit risk management techniques for banks in the region. The emergence of credit bureaus to assist banks in determining the creditworthiness of potential borrowers is another focus on managing credit risk which underscores the views that much attention has been given to containing credit risk.

Another reason why it appears regulators have concentrated on credit risk could be knowledge gap (Holland, 2010). Making regulations on any risk require extensive knowledge of its features and how it affects banks; it does appear that because CRM has been around since the 1970s, much experience has been gained making regulatory 
interventions easy (Dionne, 2013). Besides, credit risk is thought to be one major risk confronting the growth of financial institutions, and constitutes $80 \%$ of banks risks, while operational risk represents $15 \%$ and market risk, 5\% (Dionne et al., 2010). Therefore, a thorough understanding of the impact and how an institution is affected by any particular risk is essential for any policy response which is why regulatory interventions on operational risk and liquidity risk only began in the 1990s after an appreciable understanding of its features (Dionne, 2013).

Contrarily, regulatory authorities have also focused on other risks associated with banks. For instance, the Dodd-Frank Act and the European Market Infrastructure Regulation framework (EMIR) were introduced by the G-20 leaders following the systemic risk that arose after the 2008 global financial crisis (Kroon \& Lelyveld, 2018). The Dodd-Frank Act was introduced in the U.S primarily to prevent market failure which is essentially a systemic risk (Huang, 2018). The EU has also been in the forefront of tackling liquidity and systemic risk by creating the European Systemic Risk Board (ESRB) with a macroprudential responsibility to enhance the stability of the financial markets in the EU (Zidulina, 2010, p.164). Also, the EU created the Market Infrastructure Regulation framework to combat the systemic risk inherent in the over-the-counter derivative market in Europe (Bonollo et al., 2015).

The Basel Committee has also focused on other forms of risks. At the peak of the global financial crisis, the Basel Committee drafted the Principles for Sound Liquidity Risk Management and Supervision. This is essentially in the recognition of the importance of liquidity to the sustainability of the financial markets and the impact that liquidity reversal had on the global financial crises (Basel Committee, 2008 p.1). Containing liquidity and systematic risk remains an ongoing focus for central bankers, global regulatory bodies and the financial stability board (Zidulina, 2010, p.170).

Additionally, the banking committee has also taken measures to address operational risk. Following the weaknesses observed in Basel I, the Basel Committee in 2003 published the Principles for the Sound Management of Operational Risk and the Role of Supervision which is contained in Basel II (Banking Committee, 2006). The regulations covered the role of supervision, governance, and disclosures as it relates to how banks could manage their operational risk (Banking Committee, 2006.p. 144). Other regulatory bodies such as the Bank of England have also provided guidelines for operational risk which negates the assumption that regulatory authorities have only focused on credit risk. For instance, before the introduction of the operational risk component of the Basel II, the UK Banking Act of 1987 already provided a framework for deposit taking and managing a bank's operating environment (Power, 2003, p.5).

\section{Conclusion}

Regulatory interventions have focused on a broad spectrum of risks faced by banks. From the analyses above, and on a comparative note, regulatory authorities have focused more on credit risk obviously because of the impact that credit risk might have on banks if it crystallizes compare to other risks banks encounter. Despite the seeming concentration on credit risk, regulators have also focused on other forms of risks. Raft of regulatory interventions have been released to provide direction on the different risk types faced by banks albeit at a slower pace. Therefore, regulatory authorities will have to do more to provide the necessary frameworks and guidelines to cater for other risks that banks face.

Regulatory bodies might expand their interventions to cover other types of risks by first classifying the risks according to their level of impact on the banking sector in case a risk crystallizes. Having a granular understanding of the impact of these risks is essential as this will enable regulatory authorities to provide the much-needed frameworks or policies. Regulatory bodies might work with accounting bodies across the globe to design policies and frameworks around those other risks that appears not to be well-covered by regulators. This will serve the purpose of reducing the knowledge gap which seems to be a problem in the process of developing regulations while also presenting an opportunity to develop a well-articulated risk policy framework that provides direction on how to combat all forms of risks faced by banks.

\section{References}

Antoniades, A. (2014). Liquidity risk and the credit crunch of 2007-2008: Evidence from micro-level data on mortgage loan applications. Bank for International Settlements, 1-48. Retrieved October 10, 2018 from www.bis.org/publ/work473.pdf

Armour, J. C., Mayer, C., \& Polo, A. (2017). Regulatory sanctions and reputational damage in financial markets. Journal of Financial and Quantitative Analysis, 52(4), 1429-1448.

Audu, I. (2014). Risk management in the financial service industry. Central Bank of Nigeria Understanding Monetary Policy Series, 4(2), 1-34.

Balthazar, L. (2006). From Basel 1 to Basel 3: The integration of state-of-the-art risk modeling in banking regulation. Finance and Capital Market Series, doi:10.1057/9780230501171_4

Banking Committee. (2005). International convergence of capital measurement and capital standards - A revised framework. Basel Committee on Banking Supervision, 1-284. Retrieved October 5, 2018 from 
https://www.bis.org/publ/bcbs118.pdf

Basel Committee. (2006). Basel II: International convergence of capital measurement and capital standards: A revised framework. Basel Committee on Banking Supervision. Retrieved October 7, 2018 from www.bis.org/publ/bcbs128.htm

Basel Committee. (2006). International convergence of capital measurement and capital standards: A revised framework. Retrieved October 11, 2018 from https://www.bis.org/publ/bcbs128.pdf

Basel Committee. (2008). Basel committee principles for sound liquidity risk management and supervision. Retrieved October 16, 2018 from https://www.bis.org/publ/bcbs144.pdf

Basel Committee. (2013). The regulatory framework: balancing risk sensitivity, simplicity and comparability. Discussion Paper, 1-16. Retrieved October 5, 2018 from www.bis.org/publ/bcbs258.pdf

Basel Committee. (2018). History of the Basel Committee. Retrieved October 13, 2018 from www.bis.org/bcbs/history.htm

Bollard, A., Hunt, C., \& Hodgetts, B. (2011). The role of banks in the economy: Improving the performance of the New Zealand banking system after the global financial crisis. A speech delivered to New Zealand Shareholders Association Annual Meeting on December 6, 2011, 1-11.

Bonime-Blanc, A., \& Ponzi, L. J. (2017). Understanding reputation risk: The qualitative and quantitative imperative. Corporate Compliance Insights, 1-31. Retrieved October 14, 2018 from www.corporatecomplianceinsights.com/wp-content/uploads/2017/11/Understanding-Reputation-Risk-.pdf

Bonollo, M., Crimaldi, I., Flori, A., Pammolli, F., \& Riccaboni, M. (2015). Systemic risk and banking regulation: Some facts on the new regulatory framework. Institute for Advanced Studies Lucca, 1, 1-19. Retrieved October 15, 2018 from http://eprints.imtlucca.it/2455/1/EIC_WP_01_2015.pdf

Bullard, J., Neely, J. C., \& Wheelock, D. C. (2009). Systemic risk and the financial crisis: A primer. Federal Reserve Bank of St. Louis Review, 91(5), 403-417.

Cañamero, M. C. (2016). Global banking regulatory radar. Retrieved October 13, 2018 from www.moodysanalytics.com/risk-perspectives-magazine/risk-management-decade-ahead/regulatoryspotlight/global-banking-regulatory-radar

Central Bank of Nigeria. (2018). [CBN fines four banks N5.8bn, asks MTN to refund \$8bn]. Retrieved from www.cenbank.org

Danielsson, J., \& Zigrand, J. P. (2015). A proposed research and policy agenda for systemic risk. LSE Research Online. Retrieved October 11, 2018 from VoxEU.org

Decker, P. A. (2000). The changing character of liquidity and liquidity risk management: A regulator's perspective. World Bank Economic Review, 13, 379-408.

Diallo, B. S. (2015). The role of the banking sector on financial markets and economic development. Universite Du Quebec, 1-128. Retrieved October 2, 2018 from https://archipel.uqam.ca/7559/1/D2848.pdf

Dilley, B. (2008). Mortgage fraud getting serious. Frontiers in Finance - KPMG.

Dionne, G. (2013). Risk management : History, definition and critique. Working Paper, 13(2), 1-23. Retrieved October 15, 2018 from https://core.ac.uk/download/pdf/46923950.pdf

Dionne, G., Hammami, K., Gauthier, G., Maurice, M., \& Simonato, J. G. (2010). Default risk in corporate yield spreads. Financial Management, 39(2), 707-731.

EBA. (2018). EBA report on the credit risk mitigation (CRM) framework. European Bank Authority, 1-38. Retrieved October 14 2018

from www.eba.europa.eu/documents/10180/2087449/EBA+Report+on+CRM+framework.pdf

Enriques, L., \& Zetzsche, D. (2013). The risky business of regulating risk management in listed companies. European Company and Financial Law Review, 10(3), 271- 303.

Fath, G., \& Stanley, M. (2008). Counterparty Risk. Morgan Stanley, 1-42. Retrieved October 5, 2018 from http://docplayer.net/25044082-Counterparty-risk-gabor-fath-morgan-stanley.html

Gentzoglanis, A. (2014). Regulatory risk, cost of capital and investment decisions in the telecommunications industry: International comparisons. University of Sherbrooke, 1-14.

Ghenimi, A., Chaibi, H., \& Omri, A. B. (2017). The effects of liquidity risk and credit risk on bank stability: Evidence from the MENA region. Borsa Istanbul Review, 17(4), 238-248. doi:10.1016/j.bir.2017.05.002

Goodhart, C. E. (2005). Financial regulation, credit risk and financial stability. National Institute Economic Review, 192(1), 118-127. doi:10.1177/002795010519200111

Holland, J. (2010). Banks, knowledge and crisis: A case of knowledge and learning failure. Journal of Financial Regulation and Compliance, 18(2), 87-105.

Huang, Q. (2018). Impact of the Dodd-Frank Act on systemic risk: A counterfactual analysis. Social Science Research Network, 1-38. doi:10.2139/ssrn.3019977

KPMG. (2017). 10 key regulatory challenges facing the Australian Banking \& capital markets industry in 2017. Retrieved October 7, 2018 from https://assets.kpmg.com/content/dam/kpmg/au/pdf/2017/banking-capitalmarkets-regulatory-challenges-2017.pdf 
Kroon, S., \& Lelyveld, I. V. (2018). Counterparty credit risk and the effectiveness of banking regulation. $D N B$ Working Paper No 599, 1-28. Retrieved October 12, 2018 from www.dnb.nl/en/binaries/Working\%20Paper\%20No.\%20599_tcm47-377137.pdf

Lahidji, R. (2008). Summary of discussions on risk and regulation at the meeting of the group of regulatory policy. Organisation for Economic Co-operation and Development, 1-16. Retrieved October 13, 2018 from https://www.oecd.org/gov/regulatory-policy/44806674.pdf

Larkin, J. (2003). Strategic reputation risk management. New York, NY: Palgrave Macmillan.

Macey, J. R., \& Miller, G. P. (1988). Bank failures, risk monitoring and the market for bank control. Columbia Law Review, 88(6).

Malyshev, N. (2008). The evolution of regulatory policy in OECD countries. Organisation for Economic CoOperation and Development, 1-30. Retrieved October 10, 2018 from https:/www.oecd.org/gov/regulatorypolicy/41882845.pdf

Mitrovic, R., \& Ljubic, M. (2015). Globalization and its impact on contemporary banking in transition countries. WSEAS Transactions on Business and Economics, 12, 36-47.

Niepmann, F., \& Schmidt, T. (2013). International trade, risk, and the role of banks. Federal Reserve Bank of New York Staff Reports, 633, 1-77.

Ping, H. W. (2014). Banking regulatory theories. Banking Regulation in China, 27-50. doi:10.1057/9781137367556_2

Power, M. (2003). The invention of operational risk. ESRC Centre for Analysis of Banks and Regulation Discussion Paper No 16, 1-24. Retrieved October 17, 2018 from http://eprints.lse.ac.uk/21368/1/DP16.pdf

Price Water House Coopers. (2012). Managing sustainability risks and opportunities in the financial services sector. Retrieved October 3, 2018 from www.pwc.com/jg/en/publications/ned-sustainability-presentation-may2012.pdf

Radu, S. C. (2012). Globalization and its effects on financial markets. Revista Română de Statistică Trim, 1, 171175. Retrieved from www.revistadestatistica.ro/suplimente/2012/1/srrs1 2012a30.pdf

Raluca, D. O. (2012). Globalization and its effects on the banking management. Economy Series, 4, 133-36.

Rubin, G. D. (2014). Does the fact the financial sector is heavily regulated leave any place for ethics? Institute of

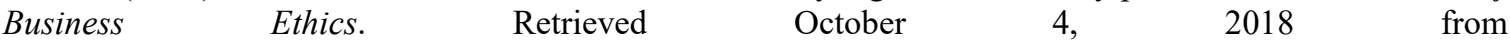
www.ibe.org.uk/userassets/otherpdfs/2014postgradwinner.pdf

Scannella, E. (2016). Theory and regulation of liquidity risk management in banking. International Journal of Risk Assessment and Management, 19(2), 4-21. doi:10.1504/IJRAM.2016.074433

Schmukler, S. (2004). Benefits and risks of financial globalization: Challenges for developing countries. World Bank Development Research Group, 1-27.

Shen, C., Chen, Y., \& Kao, F. (2009). Bank liquidity risk and performance. Review of Pacific Basin Financial Markets and Policies, 1-38. doi:10.1142/S0219091518500078

Shin, H. S. (2009). Reflections on Northern Rock: The bank run that heralded the global financial crisis. Journal of Economic Perspectives, 23(1), 101-119.

Spuchl'áková, E., Valašková, K., \& Adamko, P. (2015). The credit risk and its measurement, hedging and monitoring. Procedia Economics and Finance, 24, 675 - 681.

Ugoani, J. N. (2015). Poor credit risk management and bank failures in Nigeria. International Journal of Economics and Business Administration, 1(1), 17-24.

Vyas, S. (2012). Impact of E-banking on traditional banking services. Singhania University, Pacheri Bari, 1-4. Retrieved October 5, 2018 from https:/arxiv.org/ftp/arxiv/papers/1209/1209.2368.pdf

Weber, R. F. (2013). An alternative story of the law and regulation of risk management. Journal of Business Law, 15(4), 1005-1074. $\quad$ Retrieved $\quad$ October $6, \quad 618$ from https://pdfs.semanticscholar.org/52b4/41b59065af02c36345e9e3dfe1ce1d85ba89.pdf

Weston, R., \& Brigham, D. (1997). Managerial finance (6th ed.). London, England: Dryden Press.

Wright, S., \& Mason, R. (2003). A study into certain aspects of the cost of capital for regulated utilities in the U.K. Smithers \& Co Ltd, London.

Zidulina, T. (2010). Regulatory response to liquidity and systemic risks. Scientific Journal of Riga Technical University, 20, 164-171. 